Article

\title{
Polyethylene Glycol Pulsed Electrodeposition for the Development of Antifouling Coatings on Titanium
}

\author{
Judit Buxadera-Palomero ${ }^{1,2}$, Kim Albó ${ }^{1}$, Francisco Javier Gil ${ }^{3}$, Carlos Mas-Moruno ${ }^{1,2}$ (I) and \\ Daniel Rodríguez $1,2, *$ (D)
}

1 Biomaterials, Biomechanics and Tissue Engineering Group, Department of Materials Science and Engineering, Technical University of Catalonia (UPC), Av. Eduard Maristany, 10-14, 08019 Barcelona, Spain; judit.buxadera@upc.edu (J.B.-P.); kim.albo@upc.edu (K.A.); carles.mas.moruno@upc.edu (C.M.-M.)

2 Barcelona Research Centre in Multiscale Science and Engineering, Technical University of Catalonia (UPC), Av. Eduard Maristany, 10-14, 08019 Barcelona, Spain

3 Bioengineering Institute of Technology, International University of Catalonia, 08195 Barcelona, Spain; xavier.gil@uic.cat

* Correspondence: Daniel.rodriguez.rius@upc.edu

Received: 6 April 2020; Accepted: 6 May 2020; Published: 8 May 2020

\begin{abstract}
Titanium dental implants are widely used for the replacement of damaged teeth. However, bacterial infections at the interface between soft tissues and the implant can impair the functionality of the device and lead to failure. In this work, the preparation of an antifouling coating of polyethylene glycol (PEG) on titanium by pulsed electrodeposition was investigated in order to reduce Staphylococcus aureus (S. aureus) and Escherichia coli (E. coli) adhesion while maintaining human fibroblast adhesion. Different pulsed conditions were prepared and characterized by contact angle, Focused Ion Beam (FIB), Fourier Transformed Infrared Spectroscopy in the Attenuated Total Reflectance mode (ATR-FTIR), and X-ray photoelectron spectroscopy (XPS). XPS tested fibronectin adsorption. S. aureus, E. coli and human fibroblast adhesion was tested in vitro in both mono and co-culture settings. Physicochemical characterization proved useful for confirming the presence of PEG and evaluating the efficiency of the coating methods. Fibronectin adsorption decreased for all of the conditions, but an adsorption of $20 \%$ when compared to titanium was maintained, which supported fibroblast adhesion on the surfaces. In contrast, S. aureus and E. coli attachment on coated surfaces decreased up to $90 \%$ vs. control titanium. Co-culture studies with the two bacterial strains and human fibroblasts showed the efficacy of the coatings to allow for eukaryotic cell adhesion, even in the presence of pre-adhered bacteria.
\end{abstract}

Keywords: dental implant; antibacterial; electrodeposition; PEG; coatings

\section{Introduction}

Titanium dental implants are commonly used for the replacement of lost or damaged teeth. Even though the rate of success is around $95 \%$, infection of the surrounding tissues, known as mucositis and peri-implantitis, can significantly impair the functionality of the implant [1-4]. The soft tissue integration on the neck of the implant acts as a biological barrier, preventing bacterial attachment $[5,6]$; however, when bacterial colonization occurs, their accumulation and growth leads to the formation of a biofilm, which protects the bacteria from the host immune response and antibiotic administration $[7,8]$.

Several strategies have been developed addressing the initial stages of bacterial adhesion given the difficulty of removal of a mature biofilm. These strategies include changes on the physical and chemical properties of the implant surface (e.g., topography [9-11], wettability [12], antibacterial ions incorporation [13-15]), coating with polymers to achieve antifouling [16-18] or antibacterial effects [19], 
and the immobilization of antibiotics [20-22] or other bactericidal molecules, such as antimicrobial peptides $[23,24]$. All of the proposed methods are based on either avoiding the adhesion of bacteria or killing them by direct contact $[24,25]$.

Polyethylene glycol (PEG) is a biocompatible synthetic polyether with a wide range of different terminal modifications. When immobilized on a surface, it renders a surface hydrophilic. The amphiphilic character of PEG leads to the formation of a highly hydrated layer, responsible for the antifouling characteristics of the PEG-coated surface [26]. Several approaches have been used in order to immobilize PEG on the titanium surface [16,27], including physisorption [28], electrodeposition [23,29,30], self-assembly [31-33], and plasma polymerization [16].

Electrodeposition is a process in which an externally applied electric field attracts charged particles towards the electrode. This process has some advantages when compared to the aforementioned methods, such as short processing times, the possibility of operating at room temperature, and the use of water as solvent [34,35]. Electrochemical processes are very versatile and they can be applied to obtain a wide range of polymeric coatings, while using the applied potential to attract monomers to the substrate, where the polymerization takes place. In addition to PEG, other examples of polymeric coatings on titanium include composite coatings of alginate and chitosan [35] or the electropolymerization of dopamine [36].

However, it should be noted that the use of aqueous solutions as electrolytes implies that the electrodeposition process results in the electrolysis of water, with the subsequent formation of hydrogen bubbles in the cathode and oxygen bubbles in the anode. Such bubble formation in the vicinity of the electrodes might be detrimental, as it leads to weakly adhered and non-uniform coatings. To overcome this limitation, pulsed electrodeposition has been proven to decrease bubble formation and enhance the coating properties [37-39]. Taking into account that PEG electrodeposition has already been shown to confer antifouling properties to titanium $[27,30]$, we hypothesized that a pulsed electrodeposition of the polymer would render a thicker and more effective coating, thus further improving the biological effects of PEG. This promising strategy remains to be studied to the best of our knowledge.

Thus, in this paper, a set of PEG coatings on titanium has been developed by means of pulsed electrodeposition. Different conditions of voltage difference and pulsing time have been studied and compared with samples that were prepared in continuous mode and untreated samples in order to test the advantages of the pulsed process. The properties of the coating have been tested by means of contact angle, Focused Ion Beam (FIB), FTIR Nicolet 6700 equipment in the Attenuated Total Reflectance mode (ATR-FTIR), X-ray photoelectron spectroscopy (XPS), and SEM. The in vitro biological response was assessed by bacterial adhesion assays of Staphylococcus aureus (S. aureus) and Escherichia coli (E. coli), cell adhesion assays of human fibroblasts, and a co-culture study with the bacterial strains and fibroblasts.

\section{Materials and Methods}

\subsection{Sample Preparation}

Commercially pure titanium grade 2 (VDM metals) was obtained in $10 \mathrm{~mm}$ diameter bars and cut in disks of $2 \mathrm{~mm}$ in height, grinded with silicon carbide grinding papers (Buehler), and then polished with a colloidal silicon oxide suspension (particle size $0.05 \mu \mathrm{m}$, Buehler). Subsequently, samples were ultrasonically cleaned with acetone, ethanol, and water for $10 \mathrm{~min}$. each. All of the solvents were obtained from Sigma Aldrich. Polished and solvent-cleaned samples were used as controls and indicated as Ti.

A plasma activation process was performed to the Ti samples, as reported previously [16]. Briefly, a radio frequency low pressure plasma apparatus (Plasma System Femto, Diener, Ebhausen, Germany) was used to apply a $10 \mathrm{~min}$. treatment with argon at a pressure of $0.40 \mathrm{mbar}$. Samples treated up to this step are indicated as TiP. 


\subsection{Electrodeposition Process}

The electrodeposition was done in a two electrode electrolytic cell that was connected to a power supply. LABVIEW@software (LABVIEW 2013 SP1) was used to generate the voltage wave forms and an oscilloscope controlled the output signal (DSO1052B, Agilent Technologies) (Supplementary Information, Figures S1 and S2). The electrodeposition process was adapted from a protocol that was described by Tanaka and collaborators [30]. Briefly, $2 \% \mathrm{w} / \mathrm{w}$ of polyethylene glycol bis (3-aminopropyl) terminated (PEG-amine, $\mathrm{M}_{\mathrm{n}} \approx 1500$, Sigma Aldrich) and $0.3 \mathrm{M}$ of $\mathrm{NaCl}$ were dissolved in water. Titanium disks were placed as the cathode of the electrolytic cell, and a platinum electrode was used as the anode.

The control samples were subjected to continuous electrodeposition at $5 \mathrm{~V}$ during $5 \mathrm{~min}$. The sample code for this condition is Ti_PEG_cont. Pulsed electrodeposition was performed with a square wave according to Figure S3. Different conditions were tested by varying the frequency of the wave and the applied potential, while the total treatment time (300 s) and the duty cycle (50\%) remained constant for all of the treatments (Table 1). The pulsed times were tested for a $\Delta V=-5 \mathrm{~V}$, and using $t_{1}=t_{2}=4$, 6 and $8 \mathrm{~ms}$, respectively. The potential difference was tested at $t_{1}=t_{2}=4 \mathrm{~ms}$, and taking values of $\Delta V=-7.5,-5$ and $-2.5 \mathrm{~V}$.

Table 1. Conditions used for the electrodeposition of the titanium samples. $V_{\min }$ is the voltage applied during $t_{1}, V_{\max }$ is the maximum voltage applied during $t_{2}$. Pulsed samples are coded as Ti_PEG_ $\Delta \mathrm{V}_{-} \mathrm{T}$, where $\Delta V$ stands for the potential difference and $\mathrm{T}$ stands for the period of the wave $\left(t_{1}+t_{2}\right)$.

\begin{tabular}{ccccc}
\hline Sample Code & $\boldsymbol{V}_{\text {min }}(\mathbf{V})$ & $\boldsymbol{V}_{\text {max }}(\mathbf{V})$ & $\boldsymbol{t}_{\mathbf{1}}=\boldsymbol{t}_{\mathbf{2}}(\mathbf{m s})$ & $f(\mathbf{H z})$ \\
\hline Ti_PEG_cont & 0 & -5 & - & - \\
Ti_PEG_2.5_4 & -2.5 & -5 & 4 & 125 \\
Ti_PEG_5_4 & 0 & -5 & 4 & 125 \\
Ti_PEG_5_6 & 0 & -5 & 6 & 83.3 \\
Ti_PEG_5_8 & 0 & -5 & 8 & 62.5 \\
Ti_PEG_7.5_4 & 2.5 & -5 & 4 & 125 \\
\hline
\end{tabular}

\subsection{Surface Characterization}

Surface wettability was determined by the measurement of water contact angle while using ultra-pure MilliQ (Millipore Corporation, Burlington, MA, USA) water. OCA15 (Dataphysics, Filderstadt, Germany) equipment was used by the sessile-drop method. A $2 \mu \mathrm{L}$ droplet of water was deposited at $1 \mu \mathrm{L} / \mathrm{s}$ on the surface of the studied specimens, capturing the drop image by a video camera and analyzing it while using the SCA20 software (Dataphysics instrument Company, Filderstadt, Germany). Three measurements were carried out on three different samples for each condition.

Roughness was measured by white light interferometry using a Wyko 9300NT interferometer (Veeco, Dornach Munich, Germany). The measurements were performed in the vertical scanning interferometry mode at a 50x magnification and the data were processed with the software Wyko Vision 32 (Veeco, Dornach Munich, Germany).

Chemical characterization was undertaken by means of Infrared Spectroscopy using FTIR Nicolet 6700 equipment in the Attenuated Total Reflectance mode (ATR-FTIR, Thermofisher Scientific, Waltham, MA, USA) with a germanium crystal. 256 scans with a $2 \mathrm{~cm}^{-1}$ data spacing were recorded. X-ray photoelectron spectroscopy (XPS, SPECS Surface Nano Analysis GMbH, Berlin, Germany) was acquired in ultra-high vacuum $\left(5.0 \times 10^{-9} \mathrm{mbar}\right)$ with an XR50 Mg anode source operating at $150 \mathrm{~W}$ and a Phoibos 150 MCD-9 detector (D8 advance, SPECS Surface Nano Analysis GmbH, Berlin, Germany). The spectra were recorded at pass energy of $25 \mathrm{eV}$ with a step size of $1.0 \mathrm{eV}$ for survey spectra and $0.1 \mathrm{eV}$ for high resolution spectra. C 1 s peak was used as a reference. CasaXPS software (Casa Software Ltd, Devon, UK) was used for the determination of atomic elemental composition while applying the manufacturer set of relative sensitivity factors. As a reference to compare the XPS results, the theoretical 
atomic composition of a PEG-amine of molecular weight $1500 \mathrm{~g} / \mathrm{mol}$ was calculated by counting the number of atoms present in each polymeric chain. These values are labeled as Theoretical PEG.

Focused Ion Beam prepared the cross section of the coating (FIB Zeiss Neon40, Zeiss Oberkochen, Germany), and observed by SEM. The milling of the sample was performed at a beam current of $50 \mathrm{pA}$ and an energy of $30 \mathrm{kV}$. A platinum coating was applied by ion-beam-assisted deposition in order to protect the polymeric coating during the milling.

\subsection{In Vitro Biological Characterization}

Protein adsorption was performed with human fibronectin (Fibronectin from human serum, Sigma Aldrich). $50 \mu \mathrm{L}$ of fibronectin solution at $100 \mu \mathrm{g} / \mathrm{mL}$ in phosphate-buffered saline (PBS, Gibco, Paisley, UK) were placed on the samples and then incubated for $2 \mathrm{~h}$ at room temperature. Afterwards, the samples were washed twice with PBS and then analyzed by XPS. $\% \mathrm{~N} 1 s$ was taken as being indicative for the presence of the protein. Two samples for each condition were analyzed.

Bacterial adhesion assays were performed with S. aureus CCUG 15915 (Culture Collection University of Göteborg (CCUG, Göteborg, Sweden), and E. coli CECT 101 (Colección Española de Cultivos Tipo, Valencia, Spain). Both of the cultures were incubated from three colonies overnight at $37^{\circ} \mathrm{C}$ before the assays in Brain-Heart Infusion (BHI, Sharlab SL, Barcelona, Spain). Afterwards, bacteria suspensions were diluted to an absorbance of $0.20 \pm 0.01$ at $600 \mathrm{~nm}$ while using a Laxco MicroSpek DSM-Cuvette Cell Density Meter (Cole Parmer, Illinois, IL, USA), giving approximately $1 \times 10^{8}$ colony forming units $(\mathrm{CFU}) / \mathrm{mL} .5 \mu \mathrm{L}$ of the bacterial suspension were placed on top of the samples and left $2 \mathrm{~h}$ at $37^{\circ} \mathrm{C}$. After this time, samples were cleaned twice with PBS. Adherent bacteria were detached by vortexing the disks for $5 \mathrm{~min}$. in $1 \mathrm{~mL}$ of PBS. The detached bacteria were then seeded using serial dilutions in BHI-agar plates. The plates were then incubated overnight at $37^{\circ} \mathrm{C}$ and the resulting CFU were counted. Three samples for each condition were studied.

One sample per each condition was prepared for SEM observation (JEOL JSM-7001F, Jeol, Tokyo, Japan). With this aim, the samples were fixed with $4 \%$ paraformaldehyde in PBS and dehydrated by immersion in $50 \%, 70 \%, 90 \%, 96 \%$, and $100 \%(v / v)$ ethanol/water during $15 \mathrm{~min}$. Afterwards, the samples were coated with $\mathrm{Au} / \mathrm{Pd}$.

The potential cytotoxic effects of control and coated surfaces were evaluated according to ISO 10993-5 standard [40] on human foreskin fibroblasts (hFFs, Merck Millipore Corporation, Bedford, MA, USA), as previously reported [16]. Briefly, extracts of the samples at concentrations of 1:1, 1:10, 1:100, and 1:1000 were prepared by immersing the samples in Dulbecco's Modified Eagle Medium (DMEM, Invitrogen, Carlsbad, CA, USA). 5000 cells/well on a 96-well tissue culture polystyrene dish were in contact with the eluents for $24 \mathrm{~h}$ and then lysed with mammalian protein extraction reagent (mPER, Thermo Scientific, Waltham, MA, USA). Cell viability was measured by the activity of the enzyme lactate dehydrogenase (LDH) with a Cytotoxicity Detection Kit (Thermo Scientific, Waltham, MA, USA), as indicated by the supplier.

The cell-bacteria co-culture experiment was an adaptation from [41,42]. For cell adhesion studies, $2 \times 10^{4}$ cells were seeded on each sample and left for $24 \mathrm{~h}$ at $37{ }^{\circ} \mathrm{C}$. For co-culture experiments, a suspension of either S. aureus or E. coli was adjusted to an optical density of 0.2 in BHI, giving approximately $1 \times 10^{8} \mathrm{CFU} / \mathrm{mL} .5 \mu \mathrm{L}\left(5 \times 10^{5}\right.$ cells/sample $)$ of the bacterial suspension were seeded on each sample. After $2 \mathrm{~h}$ at $37^{\circ} \mathrm{C}$, the samples were washed three times in order to eliminate the non-attached bacteria, and hFFs in modified DMEM (DMEM with $2 \% \mathrm{BHI}$ ) at $2 \times 10^{4}$ cells/sample were seeded and incubated for $24 \mathrm{~h}$. After the incubation time, all of the samples were washed twice with PBS, fixed, and stained with Phalloidin-Rhodamine (Invitrogen) and DAPI (Invitrogen) for observation. The images were taken with a Leica TCS SPE confocal microscope and analyzed with ImageJ software. Five images were taken for each sample for the quantification, using duplicates for each condition. 


\subsection{Statistical Analysis}

The results are expressed as the average \pm standard deviation (SD), using at least three replicates. In vitro biological assays were repeated at least twice independently. Statistical analysis was performed with Minitab $17^{\mathrm{TM}}$ software (Minitab Inc, State College, PA, USA). The data were analyzed by Student's t-test and one-way ANOVA tables with Tukey's multiple comparison tests in order to evaluate outliers and statistically significant differences between the sample groups, respectively. The differences were considered to be statistically significant when $p<0.05$.

\section{Results}

\subsection{Physicochemical Characterization}

A wide range of surface characterization techniques was employed to evaluate the effect of the electrodeposition methods on the superficial properties of titanium and characterize the PEG coatings. In detail, physical properties were studied in terms of wettability and surface roughness. The thickness of the PEG layer was determined by FIB, and the chemical composition of the coatings by ATR-FTIR and XPS.

The wettability of titanium (Ti) was studied by water contact angle measurements to monitor changes in the hydrophilicity of the samples at the surface level. The wettability of Ti was increased by the plasma activation treatment, as a result of the removal of hydrophobic contaminants and the formation of polar groups, leading to a superhydrophilic surface, Ti_PA (i.e., $\theta<5^{\circ}$ ), as shown in Figure 1a. After applying the electrodeposition process, water contact angle significantly increased for all conditions to $25^{\circ}-45^{\circ}$, due to the presence of the PEG coating on the surface. All of the PEGylated samples displayed a higher wettability when compared to control Ti, in agreement with the hydrophilic character of PEG chains.

White light interferometry measurements indicated average roughness $\left(R_{a}\right)$ values of $13.2 \pm 0.2 \mathrm{~nm}$ for the bare titanium, and of $15.1 \pm 2 \mathrm{~nm}$ for the PEG coated samples. No statistically significant differences were found between these values.

Cross sections of the coatings were undertaken by focused ion beam (FIB) in the Ti_PEG_cont and Ti_PEG_5_6 in order to analyze differences in the thickness of the PEG layer between the pulsed and the continuous process (Figure 1b,c). The mean measured value of the coating thickness was $15 \mathrm{~nm}$ for the Ti_PEG_cont and $25 \mathrm{~nm}$ for the Ti_PEG_5_6, indicating higher grafting efficiency (i.e. thicker PEG layer) for the pulsed methodology, when compared to the standard procedure.
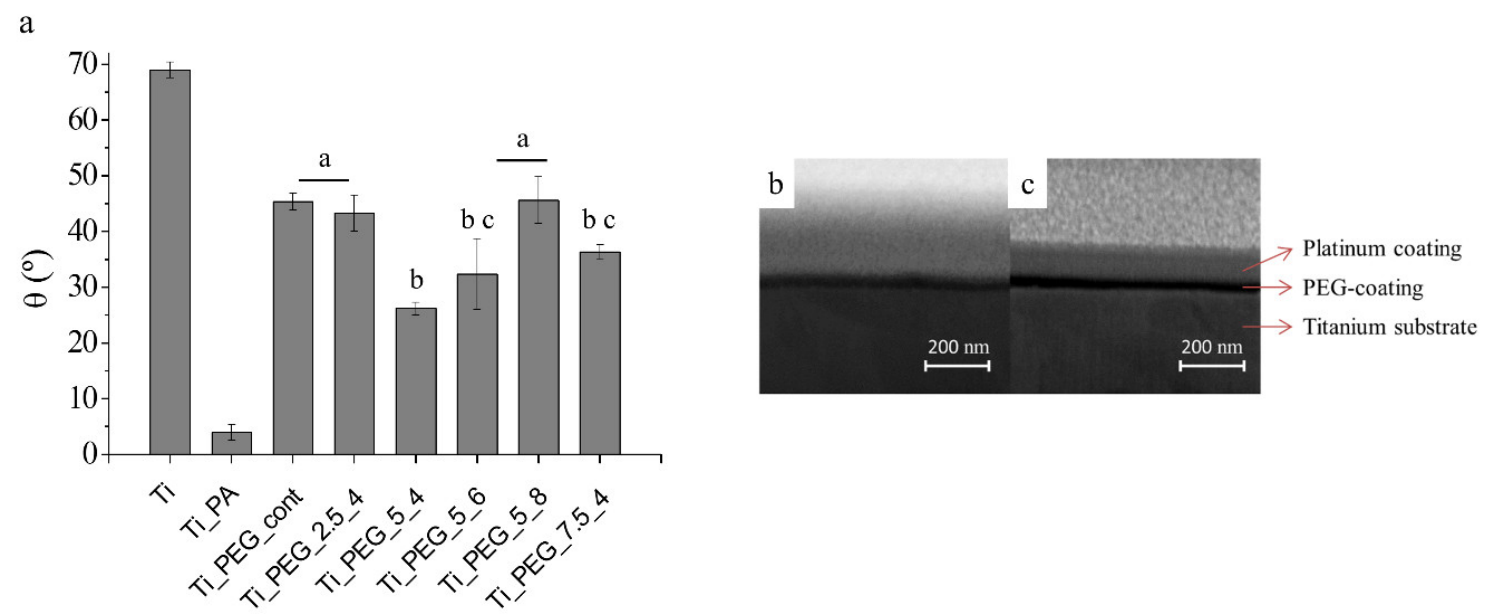

Figure 1. Water contact angle of titanium control and polyethylene glycol (PEG)-coated samples (a). Samples with the same symbol have no statistically significant differences $(p<0.05)$. Cross sections of Ti_PEG_cont (b) and Ti_PEG_5_6 (c). 
The ATR-FTIR spectra were recorded for all of the conditions giving similar results. Figure 2a shows a representative spectrum, which presented the characteristic peaks for a PEG coating. The main peaks were attributed to $-\mathrm{CH}_{2}$ bending at $963,1342,1455$, and $1465 \mathrm{~cm}^{-1}$, to $\mathrm{C}-\mathrm{O}$ stretching at 1106 and $1060 \mathrm{~cm}^{-1}$, and to $\mathrm{C}-\mathrm{C}$ stretching at $1149 \mathrm{~cm}^{-1}$.

XPS analysis of the samples revealed the presence of titanium, carbon, oxygen, and nitrogen (Table 2). Upon plasma activation (Ti_PA), a decrease of the C1s signal was observed when compared to the control Ti samples. On the contrary, continuous electrodeposition (Ti_PEG_cont) rendered an increase in the $\mathrm{C} 1 \mathrm{~s}$ signal and decrease in the Ti $2 p$ signal with respect to the non-coated samples. The same changes in chemical composition were observed for all of the coatings obtained in pulsed conditions (Ti_PEG_2.5_4, Ti_PEG_5_4, Ti_PEG_5_6, Ti-PEG_5_8 and Ti_PEG_7.5_4), but to a much higher extent, indicating a higher presence of the polymeric coating and, thus, a higher efficiency of the method. Within the pulsed conditions, Ti_PEG_7.5_4 exhibited the lowest percentage of carbon. Of note, in the pulsed mode the Ti $2 p$ signal was almost undetectable, except for the Ti_PEG_7.5_4. Similar values on the $\mathrm{N} 1 s$ signal were observed for all PEG-coated samples, both in the continuous and pulsed mode.
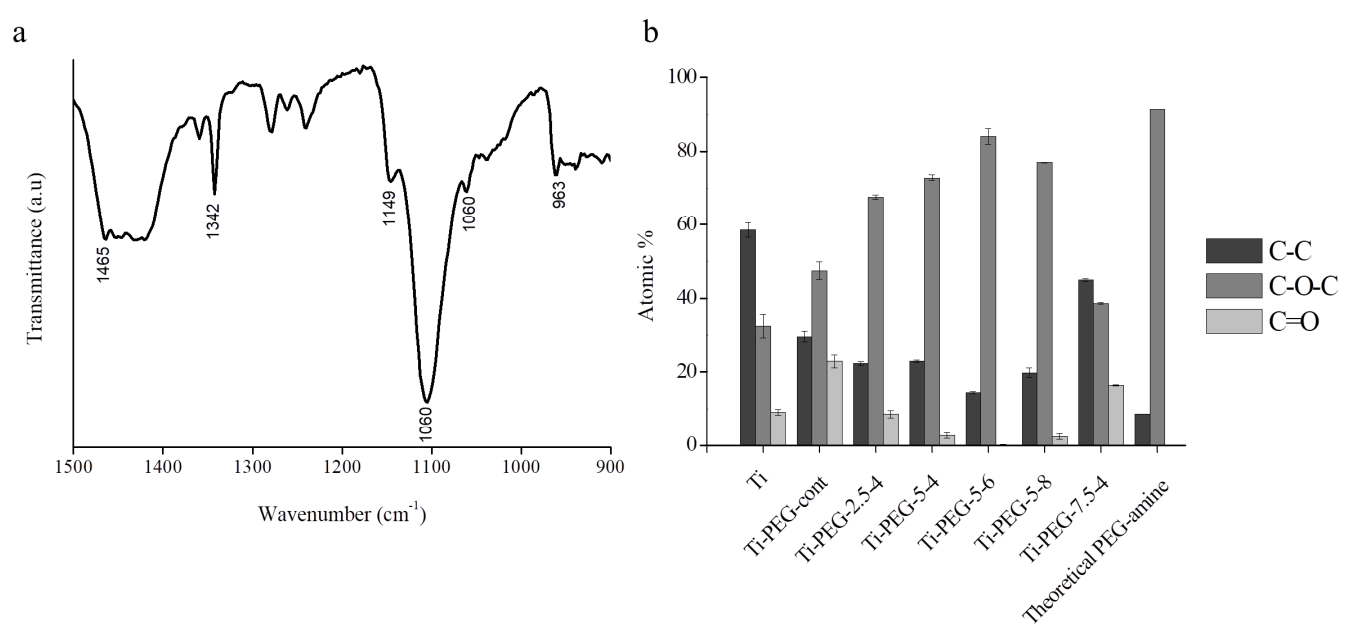

Figure 2. FTIR Nicolet 6700 equipment in the Attenuated Total Reflectance mode (ATR-FTIR) of Ti_PEG_5_6 (a), components contribution (as atomic \%) to the C 1 s peak for the X-ray photoelectron spectroscopy (XPS) decomposition (b).

Table 2. Atomic \% of the main components found on the titanium samples before and after electrodeposition, as measured by XPS.

\begin{tabular}{ccccc}
\hline Sample Code & C $1 s$ & O $1 s$ & N $1 s$ & Ti $2 p$ \\
\hline Ti & $23.5 \pm 0.8$ & $59.6 \pm 0.8$ & $0.6 \pm 0.1$ & $16.3 \pm 0.1$ \\
Ti-PA & $15.0 \pm 0.7$ & $62.1 \pm 0.7$ & $0.3 \pm 0.1$ & $22.6 \pm 0.1$ \\
Ti_PEG_cont & $38.1 \pm 0.9$ & $47.7 \pm 1.0$ & $1.2 \pm 0.1$ & $13.9 \pm 0.1$ \\
Ti_PEG_2.5_4 & $73.6 \pm 1.0$ & $24.8 \pm 0.9$ & $1.1 \pm 0.1$ & $0.1 \pm 0.2$ \\
Ti_PEG_5_4 & $70.8 \pm 0.5$ & $26.3 \pm 0.5$ & $1.0 \pm 0.1$ & $1.2 \pm 0.4$ \\
Ti_PEG_5_6 & $68.3 \pm 0.2$ & $29.2 \pm 0.2$ & $1.5 \pm 0.4$ & $0.5 \pm 0.2$ \\
Ti_PEG_5_8 & $71.9 \pm 0.6$ & $26.2 \pm 0.9$ & $1.1 \pm 0.1$ & $0.7 \pm 0.7$ \\
Ti_PEG_7.5_4 & $63.7 \pm 0.3$ & $30.1 \pm 0.2$ & $1.4 \pm 0.7$ & $4.7 \pm 0.3$ \\
Theoretical_PEG & 67.3 & 30.8 & 1.9 & - \\
\hline
\end{tabular}

The decomposition of the $\mathrm{C}$ 1s peak of the high resolution XPS spectra (Figure 3) presented three different contributions, corresponding to $\mathrm{C}-\mathrm{C}$ bonds at $285 \mathrm{eV}, \mathrm{C}-\mathrm{O}$ bonds at $286.5 \mathrm{eV}$, and $\mathrm{C}=\mathrm{O}$ bonds at $288 \mathrm{eV}$. An increase on the $\mathrm{C}-\mathrm{O}$ peak contribution was observed for all samples after electrodeposition (Figure 2b), in agreement with the presence of ether bonds. Overall, this increase was more pronounced for the pulsed conditions as compared to the continuous condition, reaching the maximum value in 
the Ti_PEG_5_6 (>80\%). This condition showed a similar pattern to the theoretical composition that was calculated for the PEG amine $(M w=1500)$. Figure 3 shows representative deconvoluted high resolution $\mathrm{C} 1 \mathrm{~s}$ spectra.

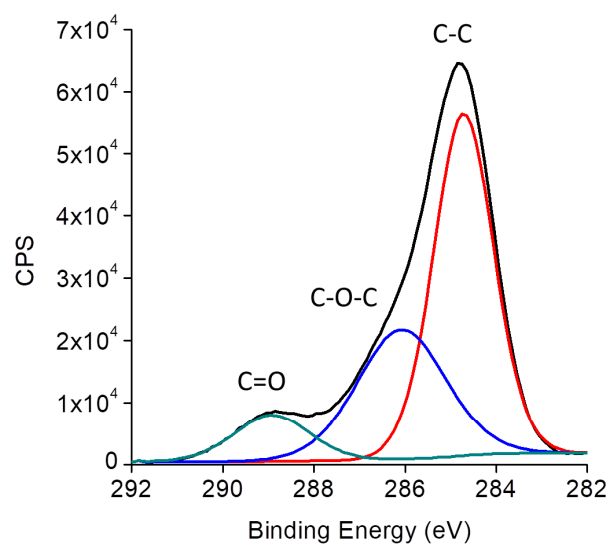

C

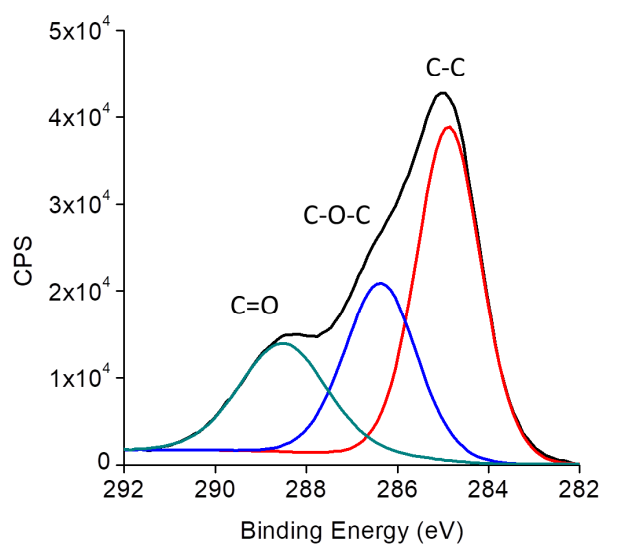

b

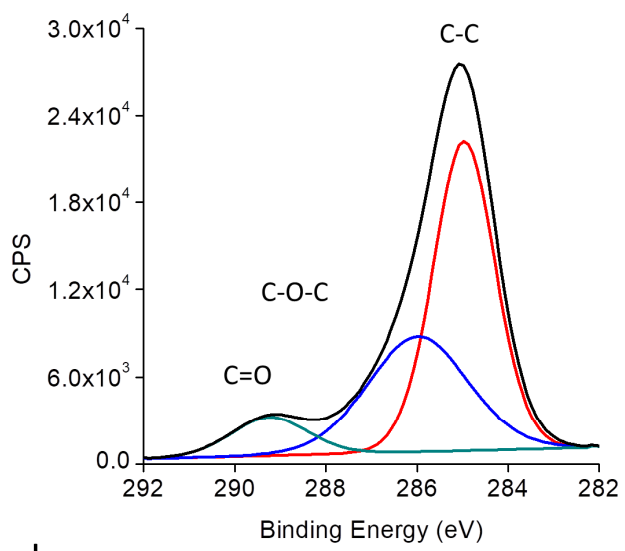

d

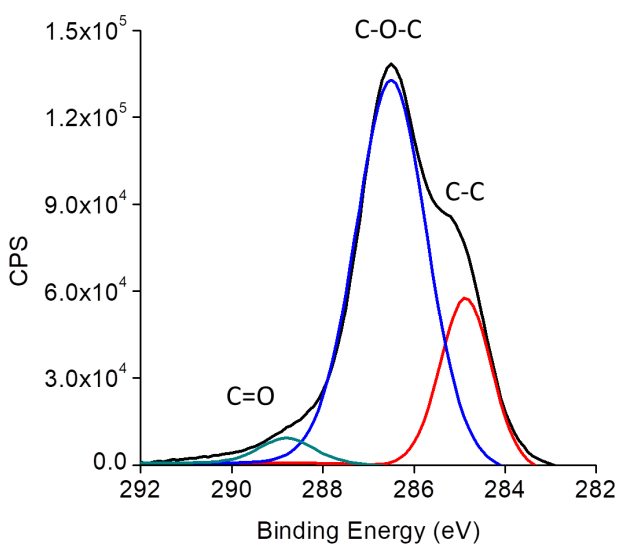

Figure 3. High resolution XPS spectra of the $\mathrm{C} 1$ s signal with the peak decomposition, corresponding to Ti (a), Ti_PA (b), Ti_PEG_cont (c), and Ti_PEG_5_4 (d).

\subsection{In Vitro Characterization}

Preventing protein adsorption is a common indicator of the antifouling potential of PEG. Thus, we selected the adhesive glycoprotein fibronectin as model protein and studied its adsorption to titanium and PEG-coated samples by XPS measuring the N 1s signal (Table 3). A decrease in the amount of protein adsorbed on the surfaces was observed for all PEG coated samples as compared to control Ti. The samples displaying the lowest protein adsorption were Ti_PEG_2.5_4 and Ti_PEG_5_8.

Table 3. Fibronectin adsorption in the samples indicated as the atomic $\%$ of the $\mathrm{N} 1 s$ by XPS.

\begin{tabular}{cc}
\hline Sample Code & N $1 s$ \\
\hline Ti & $7.9 \pm 0.2$ \\
Ti_PEG_cont & $3.1 \pm 0.7$ \\
Ti_PEG_2.5_4 & $2.7 \pm 0.9$ \\
Ti_PEG_5_4 & $5.0 \pm 0.6$ \\
Ti_PEG_5_6 & $3.27 \pm 0.02$ \\
Ti_PEG_5_8 & $2.2 \pm 0.4$ \\
Ti_PEG_7.5_4 & $5.0 \pm 0.7$ \\
\hline
\end{tabular}


Subsequently, the toxicity of the coatings and their capacity to support eukaryotic cell adhesion were investigated. Indirect cytotoxicity of the PEG-coated samples (Figure 4a) revealed no toxic effect of the eluents of the samples, as the viability of hFFs was higher than $80 \%$ for all of the conditions. hFFs adhesion values, being assessed as the $\%$ of surface area covered by cells, were statistically $(p<0.05)$ reduced on Ti_PEG_cont, Ti_PEG_5_6, Ti_PEG_5_8, and Ti_PEG_7.5_4, but they remained unaffected on Ti_PEG_2.5_4 and Ti_PEG_5_4, as compared to control Ti (Figure 4b). The average area per cell was also calculated (Figure 4c) and it showed a similar behavior to the \% of surface area covered. In terms of cell spreading and morphology (Figure $4 \mathrm{~d}-\mathrm{j}$ ), it can be observed that the cells were, in general, less spread on the samples, allowing for a lower protein adsorption (Table 3), namely Ti_PEG_cont, Ti_PEG_5_6, and Ti_PEG_5_8.
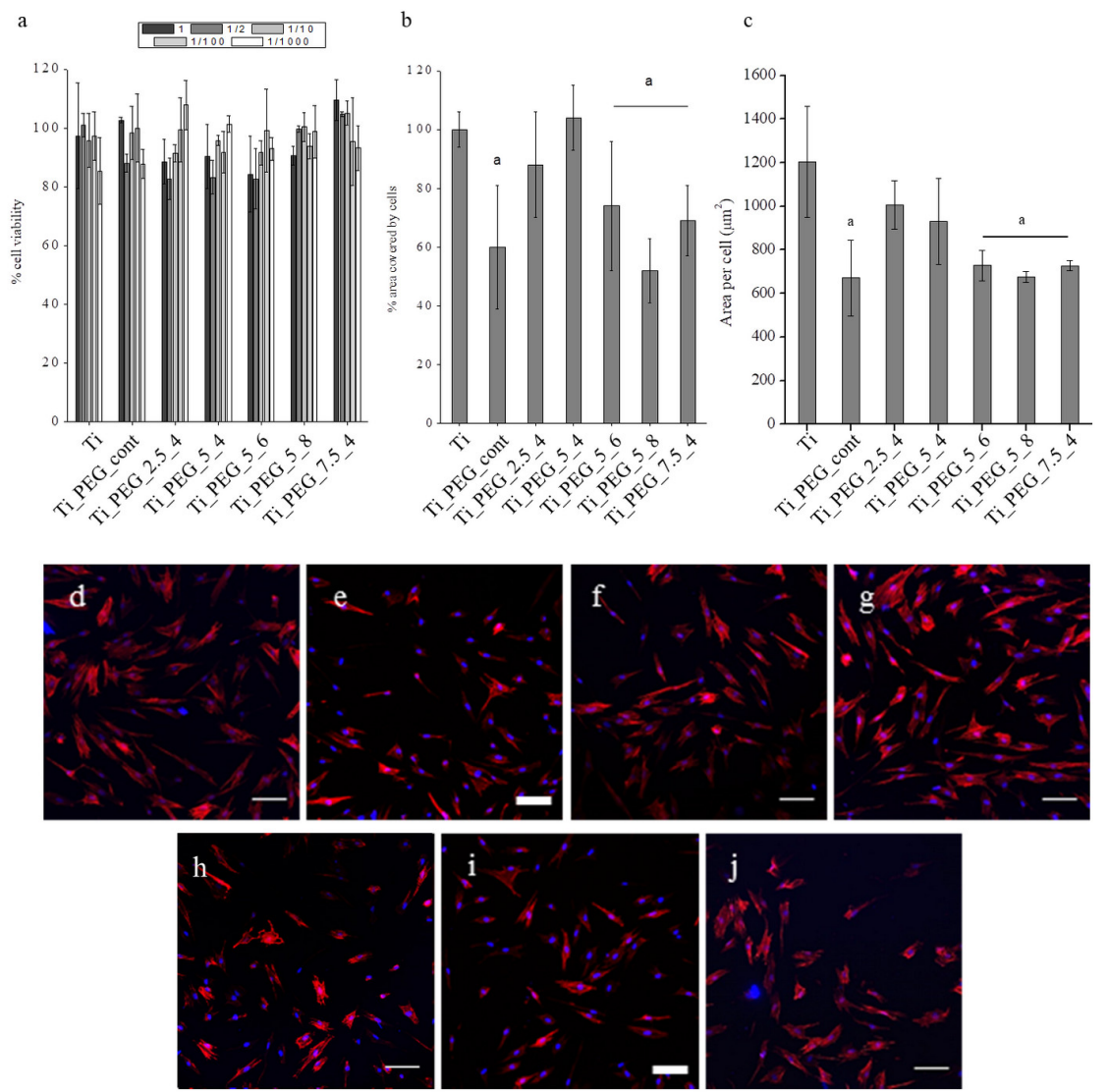

Figure 4. Indirect cytotoxicity of the PEG-coated samples (a), \% area covered by cells (b) and area per cell (c). Samples with the same symbol have no statistically significant differences $p<0.05)$ (c). Cell adhesion on the samples: Ti (d), Ti_PEG_cont (e), Ti_PEG_2.5_4 (f), Ti_PEG_5_4 (g), Ti_PEG_5_6 (h), Ti_PEG_5_8 (i), and Ti_PEG_7.5_4 (j). Scale bar indicates $100 \mu \mathrm{m}$.

The capacity of the coatings to inhibit bacterial adhesion was investigated after having studied the effect of electrodeposited PEG on protein adsorption and hFFs adhesion. In this regard, a significant decrease in the adhesion of $S$. aureus and E. coli was observed on all PEG-coated samples when compared with control samples (Figure 5). Noteworthy, when comparing the standard continuous PEGylation method (sample Ti_PEG_cont) with pulsed electrodeposition, a clear reduction in bacterial numbers was observed for the pulsed ones. This effect was statistically significant for S. aureus adhesion. However, for $E$. coli adhesion, significant differences were only obtained for the samples with $\mathrm{a} t_{\mathrm{on}}=t_{\mathrm{off}}=4 \mathrm{~ms}$, i.e. Ti_PEG_2.5_4 and Ti_PEG_7.5_4. 

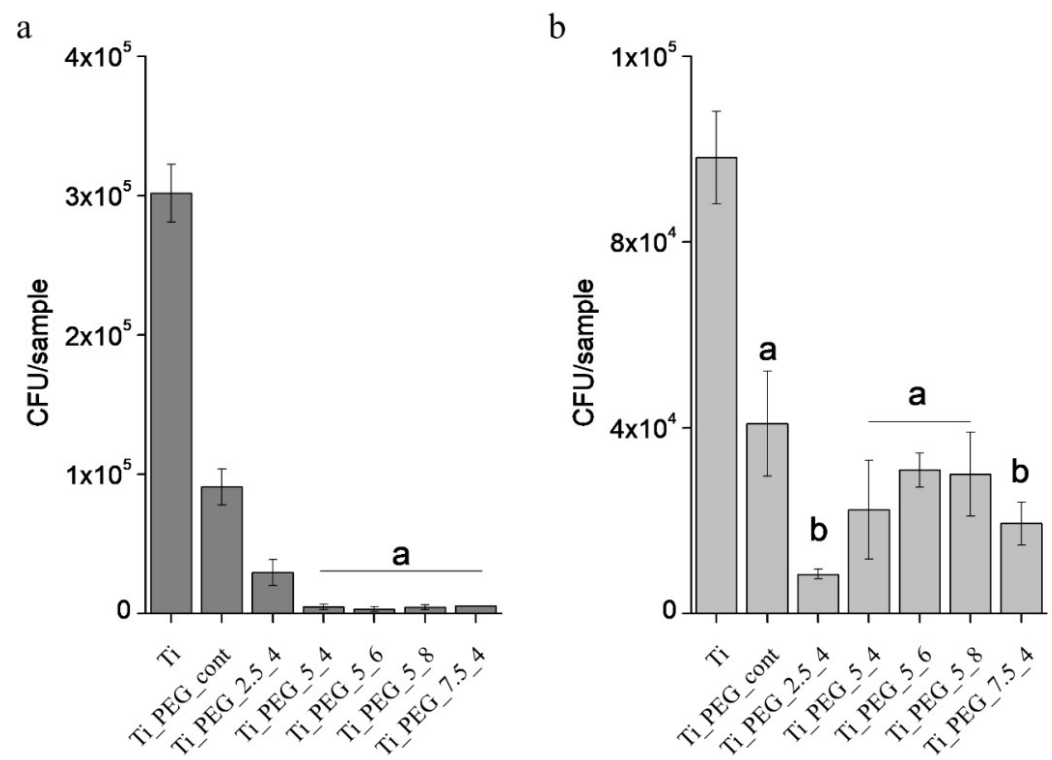

Figure 5. Bacterial adhesion on the coated sample. S. aureus adhesion (a) and E. coli adhesion (b). Samples with the same symbol have no statistically significant differences $(p<0.05)$.

The morphological features of the bacteria adhering to the substrates were observed by SEM. Regarding S. aureus adhesion (Figure 6), a clear decrease in the number of adherent bacteria can be observed when comparing the Ti samples with the PEG-coated samples. Of interest, SEM images confirmed the trend previously reported for the bacterial adhesion assay (Figure 5a), as evidenced by the much lower density of bacteria present on pulsed coated samples. Interestingly, on control Ti samples, the bacteria started producing an extracellular matrix, which was observed under and between bacteria (white arrows, Figure 6a). On Ti_PEG_cont, samples aggregation of bacteria was also observed (Figure 6b). However, the pulsed electrodeposited coatings did not show the presence of such extracellular matrix compounds, thus indicating the potential to inhibit the early stages of biofilm formation (Figure $6 \mathrm{c}-\mathrm{g}$ ).

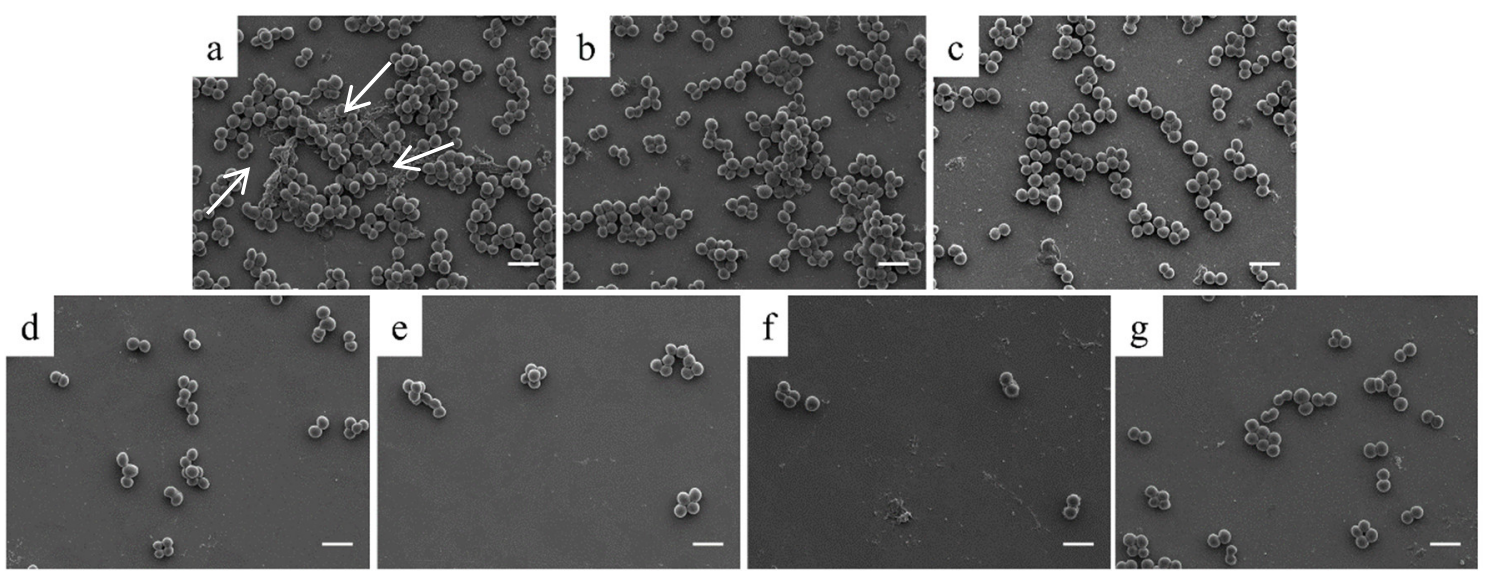

Figure 6. Representative SEM images of $S$. aureus adhering to Ti (a), Ti_PEG_cont (b), Ti_PEG_2.5_4 (c), Ti_PEG_5_4 (d), Ti_PEG_5_6 (e), Ti_PEG_5_8 (f), and Ti_PEG_7.5_4 (g). White arrows indicate the presence of an extracellular matrix characteristic of biofilm formation. Scale bar represents $2 \mu \mathrm{m}$.

SEM visualization of E. coli adhesion on Ti and PEG-coated surfaces (Figure 7) confirmed the trend that was observed in the CFU counting assay (Figure 6), i.e., PEG coatings reduced the number of bacteria, but no clear differences were observed between continuous and pulsed methods. Additionally, the reduction on the bacterial adhesion for this strain was lower than the one found for S. aureus, 
in agreement with our previous data. SEM images also evidence that the density of adhering bacteria is low enough to prevent close bacterial contacts on the samples and, therefore, biofilm formation was not observed.

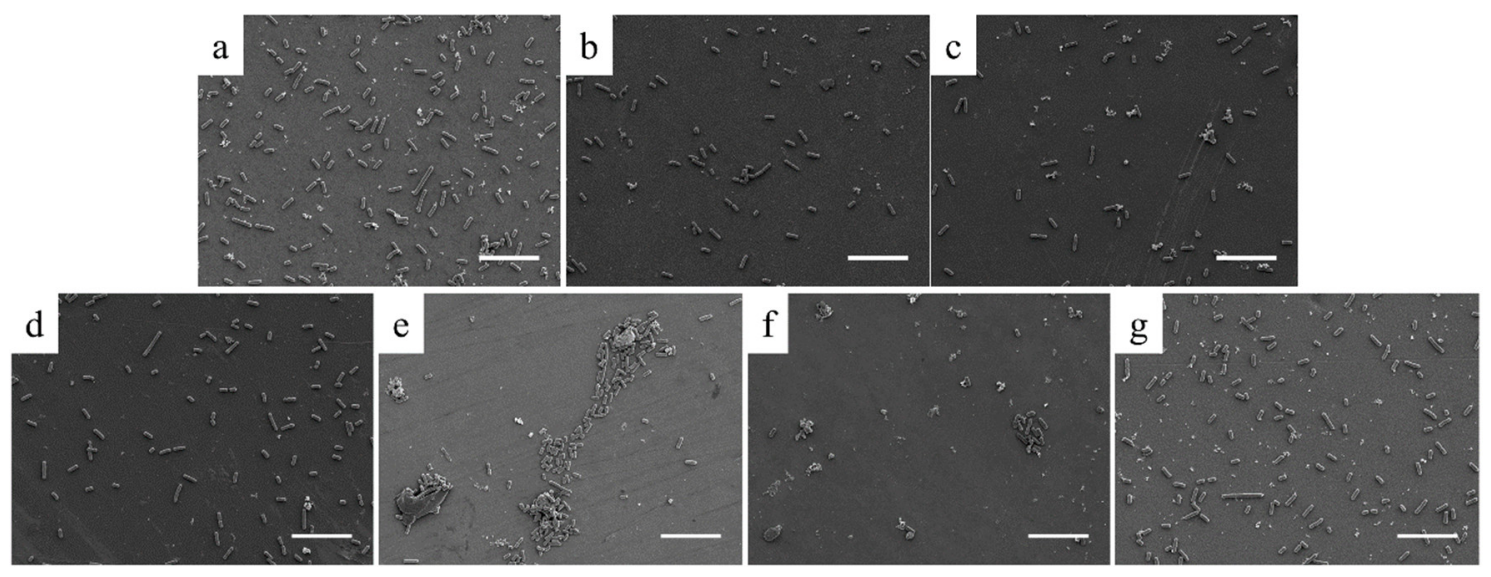

Figure 7. Representative SEM images of E. coli adhering to Ti (a), Ti_PEG_cont (b), Ti_PEG_2.5_4 (c), Ti_PEG_5_4 (d), Ti_PEG_5_6 (e), Ti_PEG_5_8 (f), and Ti_PEG_7.5_4 (g). Scale bar represents $10 \mu \mathrm{m}$.

Another relevant aspect was the differences observed on E. coli fimbriae. These appendages are used by bacteria to adhere to other bacteria, to eukaryotic cells, or to inanimate surfaces. These structures were observed on some E. coli adhered on the control surface, but not on the PEG-coated samples (Figure 8).

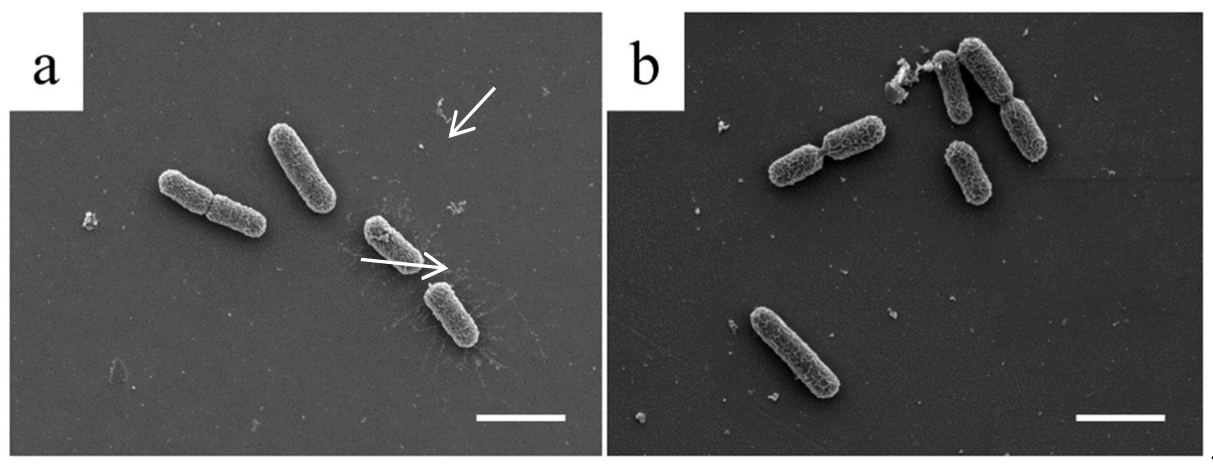

Figure 8. Magnified SEM images of E. coli adhesion on Ti (a) and Ti_PEG_5_4 (b), showing the presence of fimbriae in the bacteria adhered on the Ti sample (white arrows), but not on the Ti_PEG_5_4 sample. Scale bar represents $2 \mu \mathrm{m}$.

Finally, the capacity of the coatings to support hFFs adhesion under a "pre-infective" scenario was investigated with cell-bacteria co-culture assays. Figure 9 shows the $\%$ of area covered by cells for each treatment with respect to hFFs adhesion for the same condition without bacteria (i.e., \% of recovered adhesion). Thus, this graph illustrates the capacity of the coatings to effectively "rescue" eukaryotic cell adhesion. Interestingly, on control $\mathrm{Ti}$, the presence of bacteria was accompanied by a strong decrease in hFFs adhesion, reaching only $\sim 25 \%$ of the original values. In contrast, the PEG coatings generally increased the area covered by cells up to $50 \%$ or more, demonstrating their potential to overcome bacterial infection while allowing a certain degree of eukaryotic cell adhesion. By contrasting the performance of the different conditions that were studied against the two bacterial strains, Ti_PEG_5_8 is the condition showing a higher cell colonization recovery. 
a

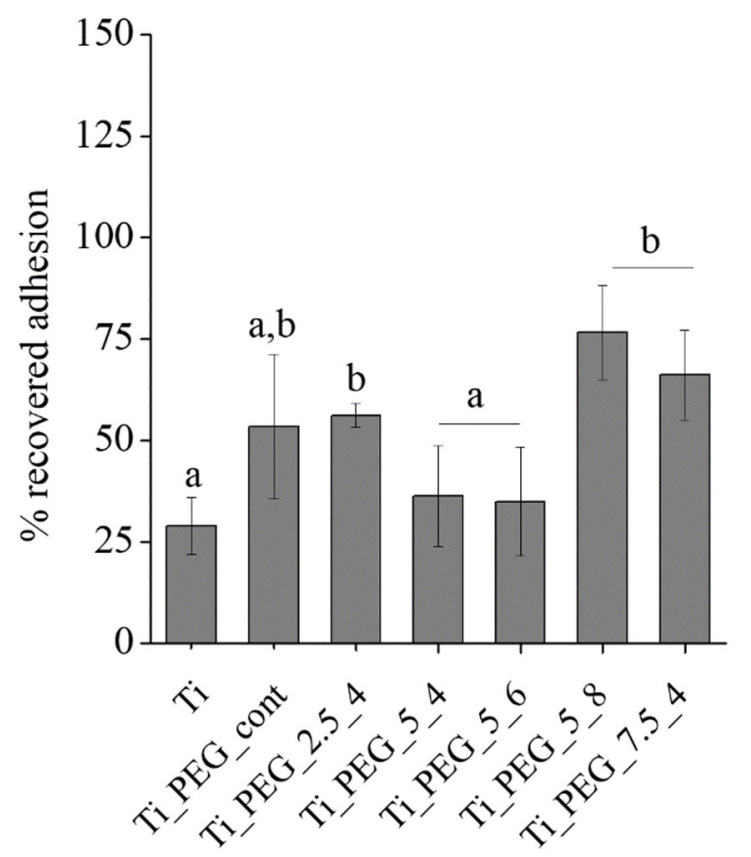

$\mathrm{b}$

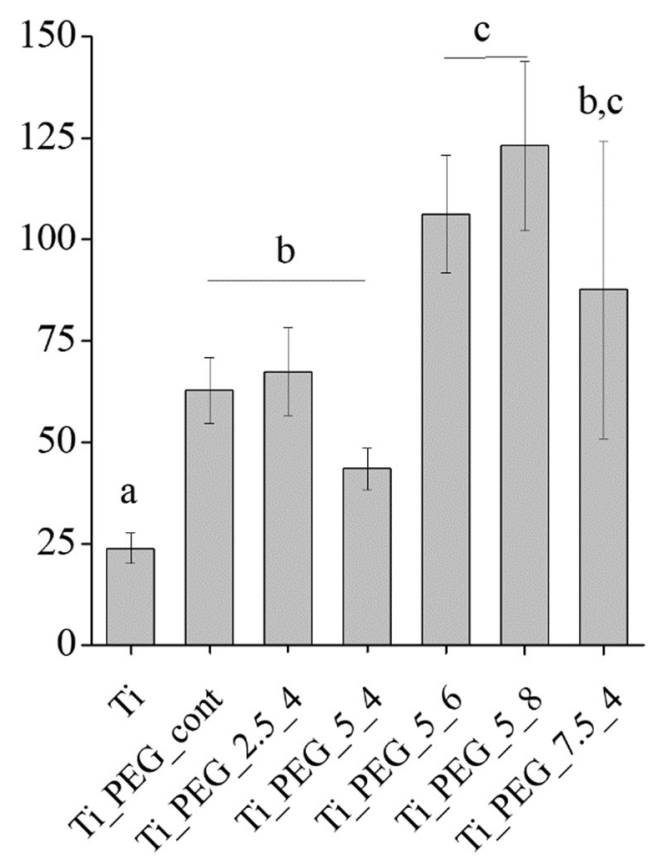

Figure 9. \% of area covered by human foreskin fibroblasts (hFFs) in the presence of S. aureus (a) and E. coli $(\mathbf{b})$, respect the area covered by cells in the sample of the same condition without bacteria. In each graph, conditions with the same letter present no statistically significant differences $(p<0.05)$.

\section{Discussion}

The use of anti-adhesive polymers, like PEG, to confer anti-fouling properties to titanium surfaces is a well-known strategy in biomaterials science and it can be achieved by a number of procedures $[16,27,43]$. Among all of the reported methods, the use of electrodeposition to coat titanium dental implants with PEG stands out as a fast and eco-friendly method for the production of functional coatings. However, gas formation as a result of water electrolysis has been described to be a major limitation [44]. Our current study focused on addressing this problem by proposing the use of pulsed electrodeposition, aiming at obtaining more homogenous and thicker coatings and, thus, improved antibacterial properties. As far as the authors of this study know, this is the report investigating this methodology to coat titanium surfaces with PEG.

In detail, we tested a series of conditions varying the voltage applied $(\Delta V)$ and frequency of the pulses $\left(t_{1}\right.$ and $\left.t_{2}\right)$ (Table 1$)$. The use of pulsed electrochemical processes to functionalize metals for biomedical applications has classically focused on inorganic coatings, including metal plating [14] or anodization [45], among others. More recently, pulsed electropolymerization has also produced polymeric coatings [39,46,47]; however, to the best of our knowledge, this method has not been thoroughly studied with PEG. Hence, the parameters that were used in this study were based on: (i) previous studies using continuous electrodeposition of PEG [27,30], (ii) reports of inorganic coatings achieved by pulsed electrodeposition $[44,48,49]$, and (iii) publications about the electropolymerization on titanium $[19,39,50]$. On the basis of these investigations, it can be concluded that both the voltage and the pulse frequency crucially affect the coating composition and morphology and, thus, by changing these parameters, different in vitro responses can be expected.

The first goal of this study was to detect the presence of PEG on titanium and analyze whether any differences were obtained when comparing the different parameters. Indeed, the physicochemical characterization confirmed the presence of a polymeric coating on all treated samples. For instance, the water contact angles that were measured for PEGylated samples were statistically different than for plain and plasma-activated titanium controls (Figure 1a) and they were in the range of wettability 
previously found for other PEG coatings [51,52]. The fact that no statistically significant differences were found in the average roughness $\left(R_{a}\right)$ values of titanium and the PEG coated samples indicated that the coatings did not modify the morphology of the samples. In addition, it has been reported that bacterial adhesion is not affected by the surface roughness below a threshold $R_{a}$ value of $200 \mathrm{~nm}[53,54]$. Thus, working with smooth samples allowed for us to exclude the effect of roughness and correlate the in vitro data unequivocally to the effects of the PEG coatings. Moreover, the ATR-FTIR measurements also confirmed the presence of the polymer, which showed the characteristic peaks of PEG [55]. XPS analysis proved useful in studying the differences among the treatments. The values of atomic composition (C 1s, O 1s, and N 1s) of the PEG layers that were obtained by pulsed electrodeposition were comparable to the theoretical values for an amino-terminated PEG with a molecular weight of 1500 (Table 2). In contrast, electrodeposition using the standard method failed to reproduce these values, thus showing the higher yield of coating obtained with the pulsed process when compared to the continuous one. Differences on the nitrogen amount may be due to the depth analysis of XPS, since the polymer layers are thicker than the analysis depth and part of the nitrogen is expected to be in contact with the titanium substrate and, hence, undetectable for the XPS.

Furthermore, an increase in the presence of the $\mathrm{C}-\mathrm{O}$ bond, which was indicative of the presence of PEG (i.e., ether bonds), was observed for the majority of pulsed conditions, when compared to continuous electrodeposition (Figures $2 \mathrm{~b}$ and 3 ). Such a result suggests a higher grafting density of the polymer chains, as previously indicated by Sharma et al. and Sofia et al. [56,57]. The higher efficiency of pulsed electrodeposition as compared to standard electrodeposition was further corroborated by SEM-FIB (Figure 1b,c), which showed a much thicker PEG layer $(\sim 25 \mathrm{~nm})$ for pulsed samples, well in agreement with the total attenuation of the Ti $2 p$ signal that was observed by XPS (Table 2). The fact that Ti_PEG_7.5_4 showed a much lower percentage of the $C$ 1s peak indicates that applying a polarity inversion results in a lower density of PEG grafting. From the $C 1$ s peak decomposition, a higher presence of the ether peak was observed in the samples with a potential difference ranging from 0 to -5 V (Ti_PEG_5_4, Ti_PEG_5_6, and Ti_PEG_5_8), showing the highest presence of the PEG coating and better surface coverage.

As expected, fibronectin adsorption was decreased by the presence of the PEG coating, as measured by the reduction in the XPS N 1s signal (Table 3); however, protein adsorption was not totally blocked, and all conditions showed nitrogen values ranging from $\sim 2 \%$ to $5 \%$. These results are in agreement with the studies of Altankov et al. and Röttgermann et al. [58,59], which showed the capability of PEG coatings to adsorb, to some extent, fibronectin, and facilitate a certain degree of cell adhesion, making the coatings viable for tissue integration applications, such as dental implants. As such, cell adhesion studies with HFFs showed that PEGylated surfaces were still able to support moderate to good levels of both cell attachment and spreading (Figure 4).

The in vitro antibacterial assays confirmed the efficiency of the electrodeposition process of PEG by the application of pulses, rendering lower bacterial adhesion rates for both Gram positive (S. aureus) and Gram negative (E. coli) bacteria, as compared to titanium (Figure 5). Tanaka et al. had previously observed the prevention of bacterial attachment with Streptococcus gordonii [60] and Buxadera-Palomero et al. with Streptococcus sanguinis and Lactobacillus salivarius [16] for samples PEGylated by continuous electrodeposition. Nonetheless, our work shows that the potential of electrodeposition can be further enhanced by applying pulses, reaching statistically higher values of bacterial inhibition than with the continuous method (Figure 5). It is noteworthy that, although HFFs adhesion was, in general, lower for the PEG-coated samples, cells were still able to adhere to the surface and spread. In particular, conditions PEG_2.5_4 and PEG_5_4 displayed the same levels of adhesion than control titanium while very effectively reduced bacterial adhesion.

In addition to lower bacterial numbers, SEM inspection of the surfaces revealed another relevant aspect. On PEG-coated samples by pulsed methods, neither bacterial extracellular matrix products (Figures 6 and 7) nor fimbriae of E. coli (Figure 8) were observed. The absence of these features highlights the fact that this strategy might be useful to also prevent, or at least significantly delay, the onset 
of biofilm formation. Moreover, biofilm development involves quorum sensing within bacteria, which requires high densities and short contact distances between bacteria. Hence, reducing the density of adhering bacteria contributes to inhibiting this process [61,62].

Finally, we tested the antibacterial effectiveness of the coatings using bacteria-cell co-culture assays (Figure 9), as these studies represent a good approach for reproducing in vitro a clinical situation of implant infection. Of note, our data showed the capacity of the PEG-coated samples to improve the biological sealing of the implant and reduce the consequences of an infection. In detail, the condition with the potential difference between 0 and $-5 \mathrm{~V}$ and the lower pulse frequency (Ti_PEG_5_8) showed the best performance in the co-culture study both with $S$. aureus and E. coli. Thus, pulsed electrodeposition of PEG represents a viable, environmentally friendly, and cost-effective method to functionalize titanium, giving rise to dual surfaces that allow for eukaryotic cell adhesion but block in vitro the "race for the surface" of bacteria [63]. Furthermore, the presence of terminal amino groups in the PEG chains offers the possibility of covalently linking biofunctional molecules, either antibacterial or cell adhesive motifs, to additionally fine tune the biological properties of the polymer $[23,27]$. Further studies evaluating the long-term stability of the coatings as well as their in vivo response in animal models are warranted in order to assess the feasibility and potential translation of this methodology to titanium dental implants.

\section{Conclusions}

A method for the pulsed electrodeposition of PEG on titanium has been reported. Our data indicated that the pulsed method rendered a higher grafting density of PEG when compared to the continuous method, which was associated with more pronounced antifouling properties and, hence, a reduction in bacterial adhesion. In general, the samples obtained with a potential difference between 0 and $-5 \mathrm{~V}$ exhibited a significant increase in the ether peak (C-O-C) of the XPS spectra, and displayed promising in vitro responses, both in terms of maintaining fibroblast adhesion and decreasing S. aureus and E. coli adhesion. In particular, pulsed electrodeposition applied at such potential difference $(\Delta V=5 \mathrm{~V})$ and higher period $\left(t_{1}=t_{2}=8 \mathrm{~ms}\right)$, i.e., Ti_PEG_5_8, yielded strong antibacterial properties and supported fibroblast adhesion, even on bacteria pre-colonized surfaces.

Supplementary Materials: The following are available online at http://www.mdpi.com/2079-6412/10/5/456/s1, Figure S1: Graphical flow diagram of the virtual interface designed for the electrodeposition control, Figure S2: User interface (front panel) for the electrodeposition control. Figure S3: Square wave used for the electrodeposition process.

Author Contributions: Conceptualization J.B.-P., F.J.G., C.M.-M., and D.R.; methodology, J.B.-P., C.M.-M., and D.R.; software, K.A.; investigation, J.B.-P. and K.A.; writing-original draft preparation, J.B.-P.; writing-review and editing, K.A., F.J.G., C.M.-M., and D.R.; supervision, F.J.G., C.M.-M., and D.R.; funding acquisition, F.J.G., C.M.-M., and D.R. All authors have read and agreed to the published version of the manuscript.

Funding: This research was funded by the Technical University of Catalonia and Fundación Ramón Areces through the fellowship of J.B.-P. Funding was also provided by Fundación Ramón Areces through project "Biosellado", and the Spanish Government through projects Nos. MAT2015-67183-R and MAT2017-83905-R, co-funded by the EU through European Regional Development Funds, and a Ramon y Cajal grant of C.M.-M. (RYC-2015-18566). The authors also thank the Government of Catalonia (Grant No. 2017 SGR-1165).

Acknowledgments: The authors wish to express their gratitude to Patricia Carrasco for her help performing experimental protocols, to Montserrat Domínguez for her useful comments and advice regarding the XPS analysis, and Trifon Trifonov for his help with the SEM-FIB measurements.

Conflicts of Interest: The authors declare no conflict of interest.

\section{References}

1. French, D.; Grandin, H.M.; Ofec, R. Retrospective cohort study of 4,591 dental implants: Analysis of risk indicators for bone loss and prevalence of peri-implant mucositis and peri-implantitis. J. Periodontol. 2019, 90, 691-700. [CrossRef]

2. Oshida, Y. Bioscience and Bioengineering of Titanium Materials; Elsevier: Amsterdam, The Netherlands, 2007; ISBN 9780080451428. 
3. Watnick, P.; Kolter, R. Biofilm, City of Microbes. J. Bacteriol. 2000, 182, 2675-2679. [CrossRef] [PubMed]

4. Hannig, C.; Hannig, M. The oral cavity-A key system to understand substratum-dependent bioadhesion on solid surfaces in man. Clin. Oral Investig. 2009, 13, 123-139. [CrossRef] [PubMed]

5. Atsuta, I.; Ayukawa, Y.; Ogino, Y.; Moriyama, Y.; Jinno, Y.; Koyano, K. Evaluations of epithelial sealing and peri-implant epithelial down-growth around "step-type" implants. Clin. Oral Implants Res. 2012, 23, 459-466. [CrossRef]

6. Chai, W.L.; Brook, I.M.; Palmquist, A.; van Noort, R.; Moharamzadeh, K. The biological seal of the implant-soft tissue interface evaluated in a tissue-engineered oral mucosal model. J. R. Soc. Interface 2012, 9, 3528-3538. [CrossRef] [PubMed]

7. Parsek, M.R.; Singh, P.K. Bacterial biofilms: An emerging link to disease pathogenesis. Annu. Rev. Microbiol. 2003, 57, 677-701. [CrossRef]

8. Costerton, J.W. Biofilm theory can guide the treatment of device-related orthopaedic infections. Clin. Orthop. Relat. Res. 2005, 7-11. [CrossRef] [PubMed]

9. Bhadra, C.M.; Khanh Truong, V.; Pham, V.T.H.; Al Kobaisi, M.; Seniutinas, G.; Wang, J.Y.; Juodkazis, S.; Crawford, R.J.; Ivanova, E.P. Antibacterial titanium nano-patterned arrays inspired by dragonfly wings. Sci. Rep. 2015, 5, 16817. [CrossRef]

10. Lorenzetti, M.; Dogša, I.; Stošicki, T.; Stopar, D.; Kalin, M.; Kobe, S.; Novak, S. The Influence of Surface Modification on Bacterial Adhesion to Titanium-Based Substrates. ACS Appl. Mater. Interfaces 2015, 7, 1644-1651. [CrossRef]

11. Fraioli, R.; Tsimbouri, P.M.; Fisher, L.E.; Nobbs, A.H.; Su, B.; Neubauer, S.; Rechenmacher, F.; Kessler, H.; Ginebra, M.-P.; Dalby, M.J.; et al. Towards the cell-instructive bactericidal substrate: Exploring the combination of nanotopographical features and integrin selective synthetic ligands. Sci. Rep. 2017, 7, 16363. [CrossRef]

12. Li, M.; Schlaich, C.; Willem Kulka, M.; Donskyi, I.S.; Schwerdtle, T.; Unger, W.E.S.; Haag, R. Mussel-inspired coatings with tunable wettability, for enhanced antibacterial efficiency and reduced bacterial adhesion. J. Mater. Chem. B 2019, 7, 3438-3445. [CrossRef]

13. Ferraris, S.; Spriano, S. Antibacterial titanium surfaces for medical implants. Mater. Sci. Eng. C 2016, 61, 965-978. [CrossRef] [PubMed]

14. Godoy-Gallardo, M.; Rodríguez-Hernández, A.G.; Delgado, L.M.; Manero, J.M.; Javier Gil, F.; Rodríguez, D. Silver deposition on titanium surface by electrochemical anodizing process reduces bacterial adhesion of Streptococcus sanguinis and Lactobacillus salivarius. Clin. Oral Implants Res. 2014, 26, 1170-1179. [CrossRef] [PubMed]

15. Tsuchiya, H.; Shirai, T.; Nishida, H.; Murakami, H.; Kabata, T.; Yamamoto, N.; Watanabe, K.; Nakase, J. Innovative antimicrobial coating of titanium implants with iodine. J. Orthop. Sci. 2012, 17, 595-604. [CrossRef]

16. Buxadera-Palomero, J.; Canal, C.; Torrent-Camarero, S.; Garrido, B.; Javier Gil, F.; Rodríguez, D. Antifouling coatings for dental implants: Polyethylene glycol-like coatings on titanium by plasma polymerization. Biointerphases 2015, 10, 029505. [CrossRef]

17. Wei, Q.; Haag, R. Universal polymer coatings and their representative biomedical applications. Mater. Horiz. 2015, 2, 567-577. [CrossRef]

18. Wei, Q.; Becherer, T.; Angioletti-Uberti, S.; Dzubiella, J.; Wischke, C.; Neffe, A.T.; Lendlein, A.; Ballauff, M.; Haag, R. Protein Interactions with Polymer Coatings and Biomaterials. Angew. Chem. Int. Ed. 2014, 53, 8004-8031. [CrossRef]

19. Ungureanu, C.; Pirvu, C.; Mindroiu, M.; Demetrescu, I. Antibacterial polymeric coating based on polypyrrole and polyethylene glycol on a new alloy TiAlZr. Prog. Org. Coat. 2012, 75, 349-355. [CrossRef]

20. De Giglio, E.; Cometa, S.; Ricci, M.A.; Cafagna, D.; Savino, A.M.; Sabbatini, L.; Orciani, M.; Ceci, E.; Novello, L.; Tantillo, G.M.; et al. Ciprofloxacin-modified electrosynthesized hydrogel coatings to prevent titanium-implant-associated infections. Acta Biomater. 2011, 7, 882-891. [CrossRef]

21. Stigter, M.; Bezemer, J.; de Groot, K.; Layrolle, P. Incorporation of different antibiotics into carbonated hydroxyapatite coatings on titanium implants, release and antibiotic efficacy. J. Control. Release 2004, 99, 127-137. [CrossRef] 
22. Rocas, P.; Hoyos-Nogués, M.; Rocas, J.; Manero, J.M.; Gil, J.; Albericio, F.; Mas-Moruno, C. Installing Multifunctionality on Titanium with RGD-Decorated Polyurethane-Polyurea Roxithromycin Loaded Nanoparticles: Toward New Osseointegrative Therapies. Adv. Healthc. Mater. 2015, 4, 1956-1960. [CrossRef] [PubMed]

23. Hoyos-Nogués, M.; Buxadera-Palomero, J.; Ginebra, M.-P.; Manero, J.M.; Gil, F.J.; Mas-Moruno, C. All-in-one trifunctional strategy: A cell adhesive, bacteriostatic and bactericidal coating for titanium implants. Colloids Surfaces B Biointerfaces 2018, 169, 30-40. [CrossRef] [PubMed]

24. Hoyos-Nogués, M.; Velasco, F.; Ginebra, M.P.; Manero, J.M.; Gil, F.J.; Mas-Moruno, C. Regenerating Bone via Multifunctional Coatings: The Blending of Cell Integration and Bacterial Inhibition Properties on the Surface of Biomaterials. ACS Appl. Mater. Interfaces 2017, 9, 21618-21630. [CrossRef] [PubMed]

25. Mas-Moruno, C.; Su, B.; Dalby, M.J. Multifunctional Coatings and Nanotopographies: Toward Cell Instructive and Antibacterial Implants. Adv. Healthc. Mater. 2019, 8, 1801103. [CrossRef]

26. Ostuni, E.; Chapman, R.G.; Holmlin, R.E.; Takayama, S.; Whitesides, G.M. A Survey of Structure-Property Relationships of Surfaces that Resist the Adsorption of Protein. Langmuir 2001, 17, 5605-5620. [CrossRef]

27. Buxadera-Palomero, J.; Calvo, C.; Torrent-Camarero, S.; Gil, F.J.; Mas-Moruno, C.; Canal, C.; Rodríguez, D. Biofunctional polyethylene glycol coatings on titanium: An in vitro-based comparison of functionalization methods. Colloids Surfaces B Biointerfaces 2017. [CrossRef]

28. Huang, Y.-W.W.; Gupta, V.K. Influence of Polymer Flux and Chain Length on Adsorption of Poly(Ethylene Oxide) on Physically Heterogeneous Surfaces. Langmuir 2002, 18, 2280-2287. [CrossRef]

29. Godoy-Gallardo, M.; Mas-Moruno, C.; Yu, K.; Manero, J.M.; Gil, J.; Kizhakkedathu, J.N.; Rodriguez, D. Antibacterial properties of hLf1-11 peptide onto titanium surfaces: A comparison study between silanization and surface initiated polymerization. Biomacromolecules 2015, 16, 483-496. [CrossRef]

30. Tanaka, Y.; Doi, H.; Iwasaki, Y.; Hiromoto, S.; Yoneyama, T.; Asami, K.; Imai, H.; Hanawa, T. Electrodeposition of amine-terminated poly(ethylene glycol) to titanium surface. Mater. Sci. Eng. C 2007, 27, 206-212. [CrossRef]

31. Hansson, K.M.; Tosatti, S.; Isaksson, J.; Wetterö, J.; Textor, M.; Lindahl, T.L.; Tengvall, P. Whole blood coagulation on protein adsorption-resistant PEG and peptide functionalised PEG-coated titanium surfaces. Biomaterials 2005, 26, 861-872. [CrossRef]

32. Huang, N.-P.; Csucs, G.; Emoto, K.; Nagasaki, Y.; Kataoka, K.; Textor, M.; Spencer, N.D. Covalent Attachment of Novel Poly(ethylene glycol)-Poly(dl -lactic acid) Copolymeric Micelles to $\mathrm{TiO}_{2}$ Surfaces. Langmuir 2002, 18, 252-258. [CrossRef]

33. Saxer, S.; Portmann, C.; Tosatti, S.; Gademann, K.; Zürcher, S.; Textor, M. Surface Assembly of Catechol-Functionalized Poly( 1 -lysine)- graft -poly(ethylene glycol) Copolymer on Titanium Exploiting Combined Electrostatically Driven Self-Organization and Biomimetic Strong Adhesion. Macromolecules 2010, 43, 1050-1060. [CrossRef]

34. Cometa, S.; Bonifacio, M.A.; Mattioli-Belmonte, M.; Sabbatini, L.; De Giglio, E. Electrochemical Strategies for Titanium Implant Polymeric Coatings: The Why and How. Coatings 2019, 9, 268. [CrossRef]

35. Wang, Z.; Zhang, X.; Gu, J.; Yang, H.; Nie, J.; Ma, G. Electrodeposition of alginate/chitosan layer-by-layer composite coatings on titanium substrates. Carbohydr. Polym. 2014, 103, 38-45. [CrossRef]

36. Wang, J.; Li, B.; Li, Z.; Ren, K.; Jin, L.; Zhang, S.; Chang, H.; Sun, Y.; Ji, J. Electropolymerization of dopamine for surface modification of complex-shaped cardiovascular stents. Biomaterials 2014, 35, 7679-7689. [CrossRef] [PubMed]

37. Chandrasekar, M.S.; Pushpavanam, M. Pulse and pulse reverse plating-Conceptual, advantages and applications. Electrochim. Acta 2008, 53, 3313-3322. [CrossRef]

38. Natter, H.; Hempelmann, R. Nanocrystalline Copper by Pulsed Electrodeposition: The Effects of Organic Additives, Bath Temperature, and pH. J. Phys. Chem. 1996, 100, 19525-19532. [CrossRef]

39. Zhou, H.; Wen, J.; Ning, X.; Fu, C.; Chen, J.; Kuang, Y. Electrosynthesis of polyaniline films on titanium by pulse potentiostatic method. Synth. Met. 2007, 157, 98-103. [CrossRef]

40. International Organization for Standardization. ISO 10993-5: Biological Evaluation of Medical Devices-Part 5: Tests for In Vitro Cytotoxicity; ISO: Geneva, Switzerland, 2009.

41. Zhao, B.; van der Mei, H.C.; Subbiahdoss, G.; de Vries, J.; Rustema-Abbing, M.; Kuijer, R.; Busscher, H.J.; Ren, Y. Soft tissue integration versus early biofilm formation on different dental implant materials. Dent. Mater. 2014, 30, 716-727. [CrossRef] 
42. Godoy-Gallardo, M.; Guillem-Marti, J.; Sevilla, P.; Manero, J.M.; Gil, F.J.; Rodriguez, D. Anhydride-functional silane immobilized onto titanium surfaces induces osteoblast cell differentiation and reduces bacterial adhesion and biofilm formation. Mater. Sci. Eng. C. Mater. Biol. Appl. 2016, 59, 524-532. [CrossRef]

43. Lo Porto, C.; Palumbo, F.; Buxadera-Palomero, J.; Canal, C.; Jelinek, P.; Zajickova, L.; Favia, P. On the plasma deposition of vancomycin-containing nano-capsules for drug-delivery applications. Plasma Process. Polym. 2018, 15, 1700232. [CrossRef]

44. Vidal, E.; Buxadera-Palomero, J.; Pierre, C.; Manero, J.M.; Ginebra, M.P.; Cazalbou, S.; Combes, C.; Rupérez, E.; Rodríguez, D. Single-step pulsed electrodeposition of calcium phosphate coatings on titanium for drug delivery. Surf. Coat. Technol. 2019, 358, 266-275. [CrossRef]

45. Quinton, D.; Galtayries, A.; Prima, F.; Griveau, S. Functionalization of titanium surfaces with a simple electrochemical strategy. Surf. Coat. Technol. 2012, 206, 2302-2307. [CrossRef]

46. Lee, H.; Dellatore, S.M.; Miller, W.M.; Messersmith, P.B. Mussel-inspired surface chemistry for multifunctional coatings. Science 2007, 318, 426-430. [CrossRef]

47. De Giglio, E.; Guascito, M.; Sabbatini, L.; Zambonin, G. Electropolymerization of pyrrole on titanium substrates for the future development of new biocompatible surfaces. Biomaterials 2001, 22, 2609-2616. [CrossRef]

48. Drevet, R.; Velard, F.; Potiron, S.; Laurent-Maquin, D.; Benhayoune, H. In vitro dissolution and corrosion study of calcium phosphate coatings elaborated by pulsed electrodeposition current on Ti6Al4V substrate. J. Mater. Sci. Mater. Med. 2011, 22, 753-761. [CrossRef]

49. Allahyarzadeh, M.; Alofkhazraei, M.; Sabour Rouhaghdam, A.; Torabinejad, V. Structure and wettability of pulsed electrodeposited Ni-W-Cu-( $\alpha$-alumina) nanocomposite. Surf. Coat. Technol. Part A 2016, 15, 525-533. [CrossRef]

50. Fukuhara, Y.; Kyuzo, M.; Tsutsumi, Y.; Nagai, A.; Chen, P.; Hanawa, T. Phospholipid polymer electrodeposited on titanium inhibits platelet adhesion. J. Biomed. Mater. Res. B. Appl. Biomater. 2015. [CrossRef]

51. Thalla, P.K.; Contreras-García, A.; Fadlallah, H.; Barrette, J.; De Crescenzo, G.; Merhi, Y.; Lerouge, S. A versatile star PEG grafting method for the generation of nonfouling and nonthrombogenic surfaces. BioMed Res. Int. 2013, 2013, 962376. [CrossRef]

52. Papra, A.; Gadegaard, N.; Larsen, N.B. Characterization of Ultrathin Poly(ethylene glycol) Monolayers on Silicon Substrates. Langmuir 2001, 17, 1457-1460. [CrossRef]

53. Teughels, W.; Van Assche, N.; Sliepen, I.; Quirynen, M. Effect of material characteristics and/or surface topography on biofilm development. Clin. Oral Implants Res. 2006, 17, 68-81. [CrossRef] [PubMed]

54. Wassmann, T.; Kreis, S.; Behr, M.; Buergers, R. The influence of surface texture and wettability on initial bacterial adhesion on titanium and zirconium oxide dental implants. Int. J. Implant Dent. 2017, 3, 32. [CrossRef] [PubMed]

55. Boru, Z.; Thomas, E.; Rico, G.; Deborah, L. Chain-length dependence of the protein and cell resistance of oligo(ethylene glycol)-terminated self-assembled monolayers on gold. J. Biomed. Mater. Res. 2001, 56, 406-416.

56. Sharma, S.; Johnson, R.W.; Desai, T.A. XPS and AFM analysis of antifouling PEG interfaces for microfabricated silicon biosensors. Biosens. Bioelectron. 2004, 20, 227-239. [CrossRef] [PubMed]

57. Sofia, S.; Premnath, V.; Merrill, E. Poly(ethylene oxide) Grafted to Silicon Surfaces: Grafting Density and Protein Adsorption. Macromolecules 1998, 31, 5059-5070. [CrossRef]

58. Altankov, G.; Thom, V.; Groth, T.; Jankova, K.; Jonsson, G.; Ulbricht, M. Modulating the biocompatibility of polymer surfaces with poly(ethylene glycol): Effect of fibronectin. J. Biomed. Mater. Res. 2000, 52, 219-230. [CrossRef]

59. Röttgermann, P.J.F.; Hertrich, S.; Berts, I.; Albert, M.; Segerer, F.J.; Moulin, J.-F.; Nickel, B.; Rädler, J.O. Cell Motility on Polyethylene Glycol Block Copolymers Correlates to Fibronectin Surface Adsorption. Macromol. Biosci. 2014, 14, 1755-1763. [CrossRef]

60. Tanaka, Y.; Matin, K.; Gyo, M.; Okada, A.; Tsutsumi, Y.; Doi, H.; Nomura, N.; Tagami, J.; Hanawa, T. Effects of electrodeposited poly(ethylene glycol) on biofilm adherence to titanium. J. Biomed. Mater. Res. A 2010, 95, 1105-1113. [CrossRef]

61. Beloin, C.; Roux, A.; Ghigo, J.M. Escherichia coli biofilms. Curr. Top. Microbiol. Immunol. 2008, 322, $249-289$. 
62. Blumer, C.; Kleefeld, A.; Lehnen, D.; Heintz, M.; Dobrindt, U.; Nagy, G.; Michaelis, K.; Emödy, L.; Polen, T.; Rachel, R.; et al. Regulation of type 1 fimbriae synthesis and biofilm formation by the transcriptional regulator LrhA of Escherichia coli. Microbiology 2005, 151, 3287-3298. [CrossRef]

63. Gristina, A.G. Biomaterial-centered infection: Microbial adhesion versus tissue integration. Science 1987, 237, 1588-1595. [CrossRef] [PubMed]

(C) 2020 by the authors. Licensee MDPI, Basel, Switzerland. This article is an open access article distributed under the terms and conditions of the Creative Commons Attribution (CC BY) license (http://creativecommons.org/licenses/by/4.0/). 